\title{
Experimental Investigations on the Performance of a Single Slope Solar Still Coupled with Shallow Solar Pond under Malaysian Conditions
}

\author{
Kamarulbaharin Z. A. ${ }^{1 *}$, Safie M. A. ${ }^{2}$, Azmi A.M. ${ }^{3}$, Singh B. S. B. ${ }^{4}$ \\ ${ }^{1234}$ Faculty of Mechanical Engineering, Universiti Teknologi MARA, 40450 Shah Alam, Malaysia \\ *Corresponding author E-mail: zainalkb@salam.uitm.edu.my
}

\begin{abstract}
Water is important to life. Deprived of water, humans can only survive for a few days. Oceans offer unlimited supply of water but it could not be ingested by humans on account of its high salt content. Desalination using fossil fuels as an energy source is expensive and may harm the environment. On the other hand, solar energy which is renewable and environmentally friendly can be used as a cheaper alternative. This paper aims to investigate the performance of a single slope solar still coupled with shallow solar pond of different design parameters under Malaysian conditions. Results showed that the performance of stills coupled with shallow solar pond is better than the ones without. The active still with the steepest condenser tilt angle $\left(20^{\circ}\right)$ yielded the highest productivity of 119 ml of water as compared to the $3^{\circ}$ tilt angle passive still $(8.5 \mathrm{ml})$.
\end{abstract}

Keywords: Desalination, Solar energy; Solar still; Solar Pond

\section{Introduction}

There are many coastal areas without access to potable water yet seawater is plentiful. Due to the high salinity content, seawater cannot be consumed [1]. As compared to freshwater where the concentration of salt is less than 1,000 parts per million (ppm), seawater contain around 35,000 ppm of dissolved salts. Removing salt from seawater or generally saline water can be done via desalination [2]. In remote areas where freshwater is deficient but solar radiation and seawater are abundant, the solar energy can be utilised as a renewable energy source to desalinate seawater into cheap potable water [3].

The operation of a solar still is similar to the natural hydrologic cycle of evaporation and condensation. The sun's rays that pass through the still's glass cover will heat up the seawater placed in the basin which will then evaporate. Subsequently, the water vapour condenses on the inner surface of the glass cover and trickle down the into the collector basin [4].

Climate parameters that affect the productivity of a solar still include solar intensity, wind velocity, and ambient temperature. Productivity can also be influenced by the cover angle, material coating on the basin, water depth, temperature difference between the water and the cover, and the insulation [5].

The evaporator basin is typically fabricated from copper, aluminium or steel [6]. The capability of the material to transfer heat is governed by the thermal conductivity of the metal. For aluminium and copper, the thermal conductivity are high at $200 \mathrm{~W} / \mathrm{m} . \mathrm{K}$ and $390 \mathrm{~W} / \mathrm{m} . \mathrm{K}$ respectively as compared to steel which is $48 \mathrm{~W} / \mathrm{m} . \mathrm{K}$. However, the cost for copper and aluminium is almost twice the cost of galvanized steel. 1 [7].

For long term applications, glass cover is more suitable as compared to plastic [8]. As the latitude angle of the test site grow larg- er, the cover tilt angle of the still should also be increased for maximum throughput [9].

There are two categories of solar stills; passive and active. Solar radiation is the only source of energy used to raise the water temperature in the evaporator basin of passive stills, leading to a lower productivity [4].

However, for active stills, additional thermal energy is supplied to the water through external means such as a solar collector, solar pond, parabolic concentrator or other devices to increase the evaporation rate and in turn improve its productivity [10]. El-Sebaii et al. [11] observed that the daily productivity and efficiency of a single slope single basin solar still combined with a shallow solar pond was higher than that of a passive still.

In this work, single slope solar stills coupled with shallow solar pond of different design parameters were fabricated utilising available local materials. The experiments were conducted to study the effects of the shallow solar pond design on single slope solar still performance under Malaysian climate.

\section{Method}

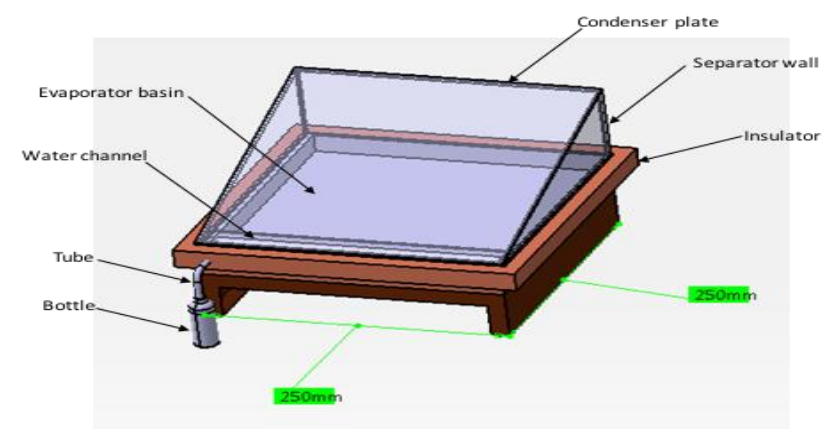


For the solar still, aluminium metal sheet of $0.5 \mathrm{~mm}$ thickness was molded into the evaporator basin and painted black throughout to improve the radiation absorption [12]. As shown in Fig. 1, the basin is $250 \mathrm{~mm} \times 250 \mathrm{~mm}$ with a height of $20 \mathrm{~mm}$ and accommodates 1 litre of saline water $(35,000 \mathrm{ppm})$ at a depth of $16 \mathrm{~mm}$. The evaporated water will condense on the inner surface of the condenser plate, flow into the inclined water channel and collected in a bottle via a tube. Both the condenser plate and the separator walls are made of $2 \mathrm{~mm}$ thick glass.

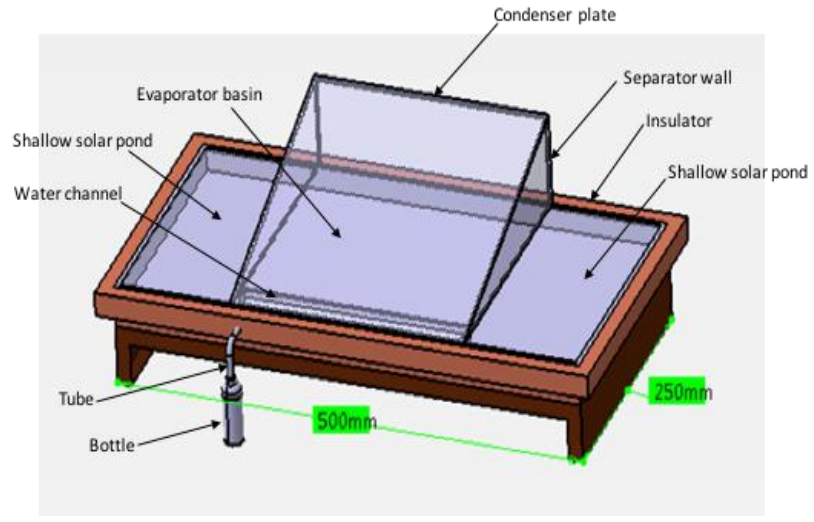

As for the solar still coupled with shallow solar pond, the still is flanked by two $125 \mathrm{~mm}$ x $250 \mathrm{~mm}$ x $20 \mathrm{~mm}$ ponds on each side

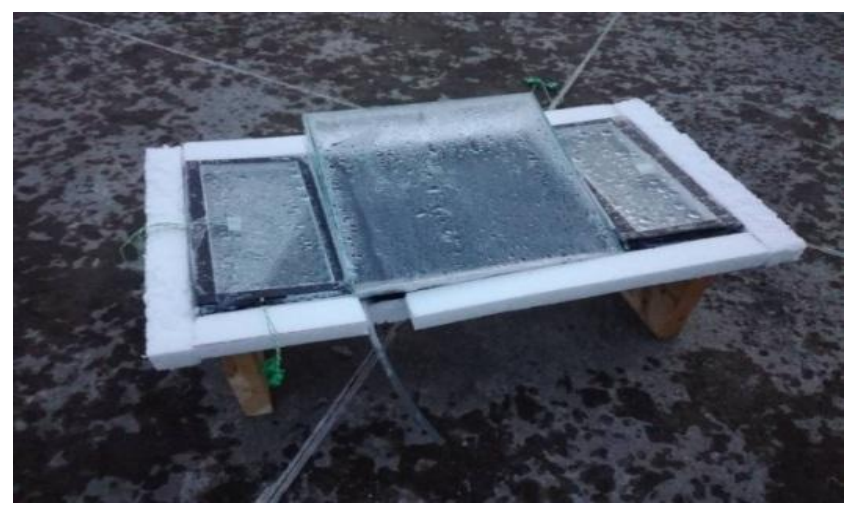

made of $0.5 \mathrm{~mm}$ thick aluminium sheet as shown in Fig. 2. The double glazed solar pond cover consists of two $2 \mathrm{~mm}$ thick glass with an air gap space of $15 \mathrm{~mm}$. As there are no walls separating the solar still evaporator and solar pond basins, they hold two litres of saline water $(35,000 \mathrm{ppm})$ at a depth of $16 \mathrm{~mm}$.

Eight stills were fabricated; four were coupled to solar ponds with different condenser plate tilt angle $\left(3^{\circ}, 10^{\circ}, 15^{\circ}\right.$, and $\left.20^{\circ}\right)$ while another four stills with the same varying condenser plate tilt angles have no solar ponds attached.

Experiments were conducted in Shah Alam, Malaysia $\left(3.0733^{\circ} \mathrm{N}\right)$ for a period of 12 hours (7 AM to 7 PM) and the stills output were measured at $2 \mathrm{~h}$ intervals. The stills were also positioned in the East-West direction (elevation angle) to study its effect on the stills performance.

The ambient temperature and relative humidity were measured with a Sunleaves Hygro-Thermometer and Type K thermocouples (chromel-alumel) were attached to specific points on the still to record the temperatures. Water salinity values were determined using a SENSION 7 Benchtop Conductivity Meter.

\section{Results and Discussion}

Fig. 3 shows the comparison between the ambient temperature and water temperatures in the evaporator basins of the solar stills.

\begin{tabular}{|l|l|}
\hline Nomenclature & \\
\hline A & $\begin{array}{l}\text { Solar still with 3o condenser plate without } \\
\text { shallow solar pond }\end{array}$ \\
\hline B & $\begin{array}{l}\text { Solar still with 10o condenser plate without } \\
\text { shallow solar pond }\end{array}$ \\
\hline C & $\begin{array}{l}\text { Solar still with 15o condenser plate without } \\
\text { shallow solar pond }\end{array}$ \\
\hline D & $\begin{array}{l}\text { Solar still with 20o condenser plate without } \\
\text { shallow solar pond }\end{array}$ \\
\hline AA & $\begin{array}{l}\text { Solar still with 3o condenser plate coupled } \\
\text { with shallow solar pond }\end{array}$ \\
\hline BB & $\begin{array}{l}\text { Solar still with 10o condenser plate coupled } \\
\text { with shallow solar pond }\end{array}$ \\
\hline CC & $\begin{array}{l}\text { Solar still with 15o condenser plate coupled } \\
\text { with shallow solar pond }\end{array}$ \\
\hline DD & $\begin{array}{l}\text { Solar still with 20o condenser plate coupled } \\
\text { with shallow solar pond }\end{array}$ \\
\hline
\end{tabular}

Water temperature in basin

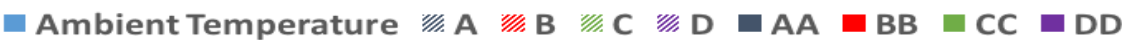

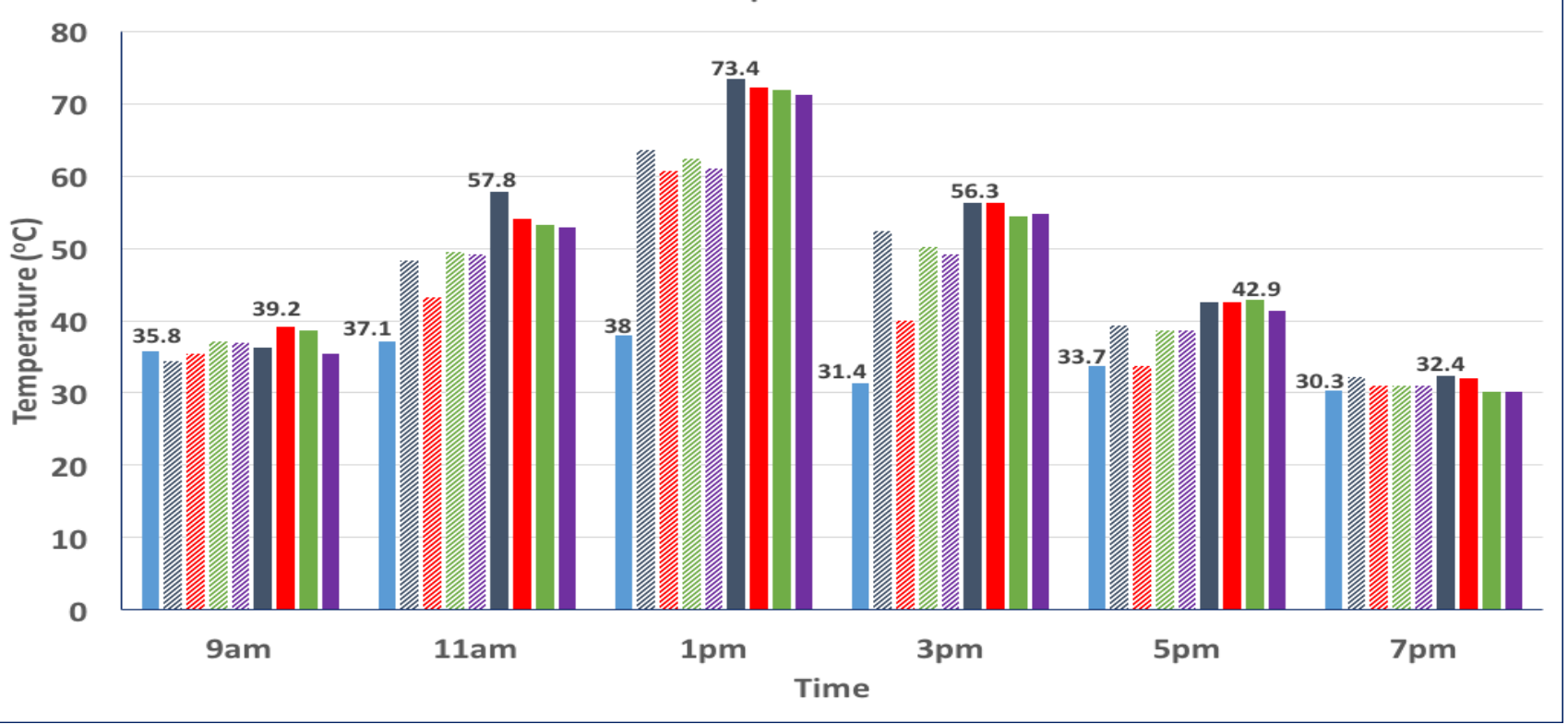




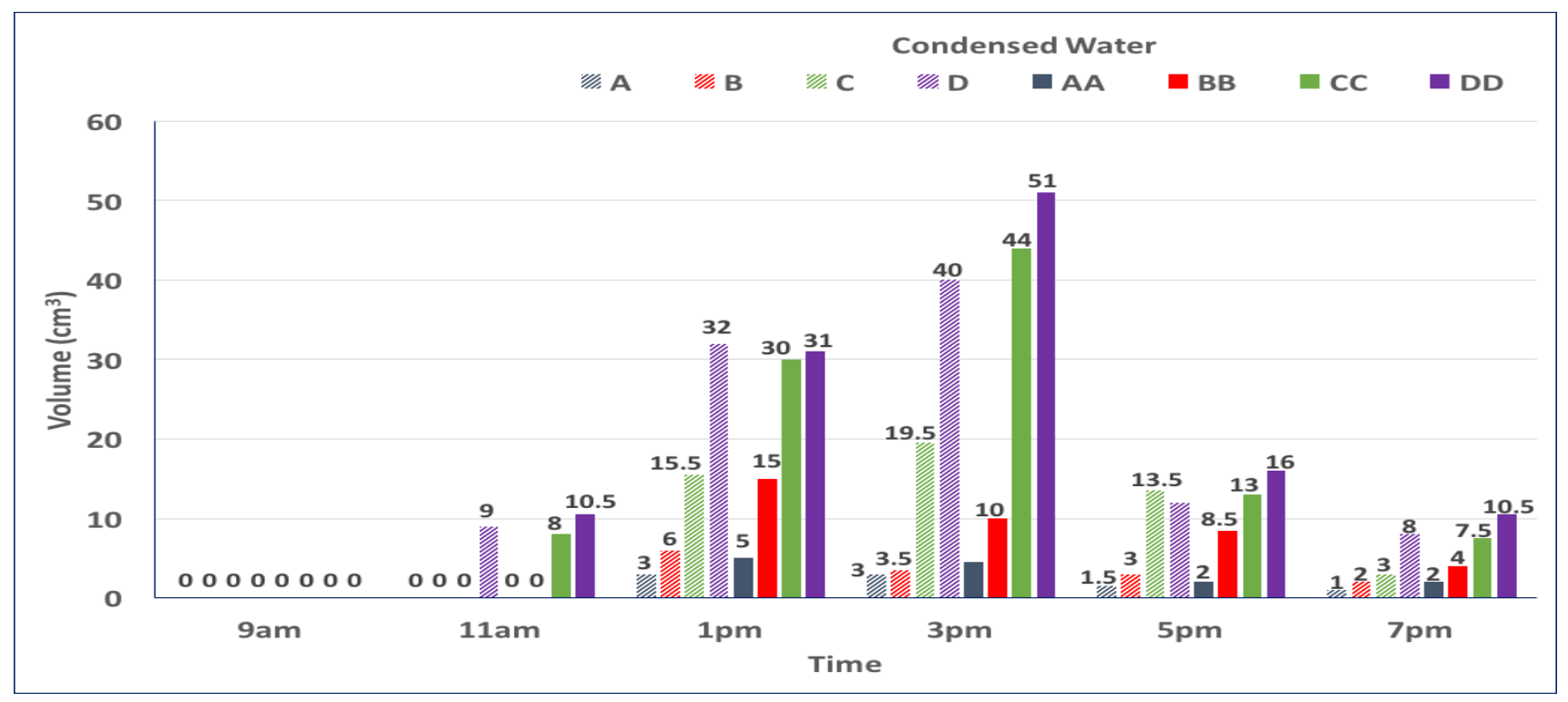

From the graph, water temperatures in all the evaporator basins showed a steady increase from 9 am until peaking at $1 \mathrm{pm}$. The water temperatures for all the stills coupled with shallow solar pond also surpass all the passive stills at this hour. The highest water temperature recorded was in active solar still AA at $73.4{ }^{\circ} \mathrm{C}$ and the lowest is passive still $\mathrm{B}$ at $60.7^{\circ} \mathrm{C}$. It can be ascertained that the active solar stills are able to heat the water in the evaporator basin to a higher temperature with the extra thermal energy supplied by the shallow solar pond and this is supported by Shafii et al [10]. A gradual decline in water temperatures in all the basins were recorded from $1 \mathrm{pm}$ until $7 \mathrm{pm}$ and correlates with the finding by Ahsan et al. [13] that solar energy is highest at midday and begin to decrease after that.

Fig. 4 shows the volume of condensed water over time for all eight solar stills.

The condensation rate in the stills showed a measured increase from 11 am until cresting at 3 pm before gradually declining subsequently. Active solar still DD recorded the highest condensation of $51 \mathrm{ml}$ at $3 \mathrm{pm}$ while passive still A recorded the lowest amount. These values seem to correlate with the water temperatures in the basins shown in Fig. 3 as higher temperatures would increase the evaporation rate which may in turn intensify the condensation rate. Table 1 shows the productivity of the solar stills. Total evaporation volume for active solar still DD is highest at $550 \mathrm{ml}$ and still AA is lowest at $118 \mathrm{ml}$. In terms of total volume of condensed water collected, active still DD again produced the highest amount at $119 \mathrm{ml}$ while passive still A yielded the lowest $(8.5 \mathrm{ml})$. Similiarly, both passive still D and active still DD with the steepest condenser plate tilt angle $\left(20^{\circ}\right)$ displayed high condensation versus evaporation ratios. It is likely that the steeper incline increases the droplets speed travelling along the interior surface of the condenser plate into the water channel instead of falling back into the basin as compared to the other stills and this is concurred by Khalifa [9].

Table 1: Solar stills productivity

\begin{tabular}{|c|c|c|c|}
\multicolumn{5}{|c|}{ Table 1: Solar stills productivity } \\
\hline $\begin{array}{c}\text { Solar } \\
\text { Still }\end{array}$ & $\begin{array}{c}\text { Evaporation } \\
(\mathrm{ml})\end{array}$ & $\begin{array}{c}\text { Condensation } \\
(\mathrm{ml})\end{array}$ & $\begin{array}{c}\text { Condensation/Evaporation } \\
(\%)\end{array}$ \\
\hline A & 120 & 8.5 & 7.1 \\
\hline B & 200 & 12.5 & 6.3 \\
\hline C & 250 & 51.5 & 20.6 \\
\hline D & 300 & 101.0 & 33.7 \\
\hline AA & 118 & 13.5 & 11.4 \\
\hline BB & 350 & 37.5 & 10.7 \\
\hline CC & 500 & 102.5 & 20.5 \\
\hline DD & 550 & 119.0 & 21.6 \\
\hline
\end{tabular}

In contrast, higher temperatures inside active still DD may lead to a lower condensation/evaporation ratio as compared to the passive still D and is corroborated by Kabeel and El-Agouz [14]. A lower cover temperature will also help to increase the condensation.

The salinity of the condensed water for all the stills are less than 1,000 ppm (Table 2) and can thus be safely ingested by humans.

Table 2: Salinity of water in the evaporator basin and condensed water

\begin{tabular}{|c|c|c|c|}
\hline \multirow{2}{*}{ Solar Still } & \multicolumn{2}{|c|}{ Evaporator Basin } & \multirow{2}{*}{$\begin{array}{c}\text { Condensed } \\
\text { Water } \\
(\mathrm{ppm})\end{array}$} \\
\cline { 2 - 3 } & $\begin{array}{c}\text { Before } \\
(\mathrm{ppm})\end{array}$ & $\begin{array}{l}\text { After } \\
(\mathrm{ppm})\end{array}$ & 400 \\
\hline A & 35000 & 36400 & 500 \\
\hline B & 35000 & 38600 & 400 \\
\hline C & 35000 & 40700 & 400 \\
\hline D & 35000 & 42000 & 400 \\
\hline AA & 35000 & 37500 & 500 \\
\hline BB & 35000 & 40600 & 500 \\
\hline CC & 35000 & 39000 & 600 \\
\hline DD & 35000 & 42500 & \\
\hline
\end{tabular}

\section{Conclusion}

The performance of single slope solar still coupled with shallow solar pond was experimentally studied and compared to passive solar still under Malaysian conditions. The active still with the steepest condenser tilt angle $\left(20^{\circ}\right)$ yielded the highest productivity of $119 \mathrm{ml}$ of water as compared to the $3^{\circ}$ tilt angle passive still $(8.5 \mathrm{ml})$. Higher temperatures inside the stills will generate higher evaporation rates but will lower the condensation rate at the inner cover surface. The processed water salinity of less than 1,000 ppm also makes it safe for human consumption. From this investigation, it can therefore be concluded that an active still with a $20^{\circ}$ condenser plate tilt angle will give the best production rate of fresh water.

\section{Acknowledgement}

This work was supported by the Lestari Research Grant 600 IRMI/DANA 5/3/LESTARI (0036/2016) under the Institute of Research Management \& Innovation, Universiti Teknologi MARA. The authors would also like to thank the Faculty of Mechanical Engineering and the Faculty of Civil Engineering; Universiti Teknologi MARA for the technical assistance provided which made this study possible. 


\section{References}

[1] V. Sivakumar and E. Ganapathy Sundaram, "Improvement techniques of solar still efficiency: A review," Renew. Sustain. Energy Rev., vol. 28, pp. 246-264, 2013.

[2] "U.S. Geological Survey's (USGS) Water Science School." [Online]. Available: http://water.usgs.gov/edu/saline.html.

[3] M. S. S. Abujazar, S. Fatihah, A. R. Rakmi, and M. Z. Shahrom, "The effects of design parameters on productivity performance of a solar still for seawater desalination: A review," Desalination, vol. 385, pp. 178-193, 2016.

[4] K. Sampathkumar, T. V. Arjunan, P. Pitchandi, and P. Senthilkumar, "Active solar distillation-A detailed review," Renew. Sustain. Energy Rev., vol. 14, no. 6, pp. 1503-1526, 2010.

[5] G. Xiao, X. Wang, M. Ni, F. Wang, W. Zhu, Z. Luo, and K. Cen, "A review on solar stills for brine desalination," Appl. Energy, vol. 103, pp. 642-652, 2013.

[6] C. L. Martin and D. Y. Goswami, Solar Energy Pocket Reference. Earthscan, 2005.

[7] A. Muthu Manokar, K. Kalidasa Murugavel, and G. Esakkimuthu, "Different parameters affecting the rate of evaporation and condensation on passive solar still - A review," Renew. Sustain Energy Rev., vol. 38, pp. 309-322, 2014.

[8] H. M. Qiblawey and F. Banat, "Solar thermal desalination technologies," Desalination, vol. 220, no. 1-3, pp. 633-644, 2008.

[9] A. J. N. Khalifa, "On the effect of cover tilt angle of the simple solar still on its productivity in different seasons and latitudes," Energy Convers. Manag., vol. 52, no. 1, pp. 431-436, 2011.

[10] M. B. Shafii, M. Shahmohamadi, M. Faegh, and H. Sadrhosseini, "Examination of a novel solar still equipped with evacuated tube collectors and thermoelectric modules," Desalination, vol. 382, pp 21-27, 2016.

[11] P. Vishwanath Kumar, A. Kumar, O. Prakash, and A. K. Kaviti, "Solar stills system design: A review," Renew. Sustain. Energy Rev. vol. 51, pp. 153-181, 2015.

[12] M. M. Morad, H. A. M. El-Maghawry, and K. I. Wasfy, "Improving the double slope solar still performance by using flatplate solar collector and cooling glass cover," Desalination, vol. 373, pp. 1-9, Oct. 2015.

[13] A. Ahsan, M. Imteaz, U. A. Thomas, M. Azmi, A. Rahman, and N. N. Nik Daud, "Parameters affecting the performance of a low cost solar still," Appl. Energy, vol. 114, pp. 924-930, 2014.

[14] A. E. Kabeel and S. A. El-Agouz, "Review of researches and developments on solar stills," Desalination, vol. 276, no. 1-3, pp. 1-12, Aug. 2011. 